\title{
OCHRONA PRZYRODY I ŚRODOWISKA W DYSKURSIE „NEWSWEEKA” I „TYGODNIKA POWSZECHNEGO”
}

\section{WPROWADZENIE}

Warunki środowiskowe i przyrodnicze, poza czynnikami ekonomicznymi, a także poczuciem bezpieczeństwa i prawem do wolności, stanowią ważny element determinujący kondycję współczesnych społeczeństw. Zważywszy, że przy dokonywaniu oceny jakości ludzkiego życia wpływ otoczenia przyrodniczego bywa przez wielu badaczy na ogół pomijany, autorka postanowiła zbadać, w jaki sposób w dyskursie medialnym prezentowany jest temat ochrony przyrody i środowiska. W tym celu do analizy wybrane zostały dwa tygodniki: „Newsweek Polska” $(N)$ i „Tygodnik Powszechny” (TP). Analizie poddane zostały teksty poruszajace kwestie ochrony przyrody i zagrożeń środowiska, które ukazały się w nich w 2015 i 2016 r.

Celem niniejszego artykułu jest dokonanie krytycznej analizy dyskursu prasowego (KAD); KAD stanowi zarówno podejście teoretyczne, jak i metodę jakościową. Za pomoca wybranych wątków KAD podjęta została próba określenia sposobu, w jaki w obu tygodnikach prezentowana i kształtowana była rzeczywistość środowiskowa i przyrodnicza. W artykule weryfikacji poddano ponadto hipotezy zakładające, że w $N$ częściej podejmowany był temat ochrony i zagrożeń środowiska, przy czym przedstawiany był on raczej z perspektywy globalnej z uwzględnieniem wymiaru moralnego. W proponowanych hipotezach stwierdzono także, że w TP kwestie środowiskowe kształtowane były częściej przez pryzmat czynników ekonomicznych i dotyczyły skali lokalnej. Autorka założyła ponadto, że w $N$ częściej niż w $T P$ prezentowano i propagowano postawy proekologiczne.

Aby sprecyzować temat, należy zdefiniować dwa występujace w tytule terminy, mianowicie: „ochrona przyrody” i „ochrona środowiska”. Zgodnie z polską ustawą z 27 kwietnia 2001 r. Prawo ochrony środowiska, ochrona środowiska rozumiana jest jako „podjęcie lub zaniechanie działań, umożliwiające zachowanie lub przywracanie równowagi przyrodniczej; ochrona ta polega w szczególności na: a) racjonalnym kształtowaniu środowiska i gospodarowaniu zasobami środowiska zgodnie z zasadą zrównoważonego rozwoju, b) przeciwdziałaniu zanieczyszczeniom c) przywracaniu elementów przyrodniczych do stanu właściwego"1. Z kolei według ustawy z 16 kwietnia 2004 r. o ochronie

${ }^{1}$ Dz. U. 2001, Nr 62, poz. 627. 
przyrody: „ochrona przyrody polega na: zachowaniu, zrównoważonym użytkowaniu oraz odnawianiu zasobów, tworów i składników przyrody: a) dziko występujących roślin, zwierząt i grzybów; b) roślin, zwierząt i grzybów objętych ochrona gatunkowa; c) zwierząt prowadzacych wędrowny tryb życia; d) siedlisk przyrodniczych; e) siedlisk zagrożonych wyginięciem, rzadkich i chronionych gatunków roślin, zwierząt i grzybów; f) tworów przyrody żywej i nieożywionej oraz kopalnych szczątków roślin i zwierząt; g) krajobrazu; h) zieleni w miastach i wsiach; i) zadrzewień. [...]"2. Mimo że trudno wyznaczyć ostrą granicę między wspomnianymi pojęciami, można stwierdzić, że ochrona przyrody polega głównie na zachowaniu i odpowiedzialnym wykorzystywaniu zasobów przyrodniczych. Badania na ten temat prowadzili m.in. James Aronson $^{3}$, Michael Gross ${ }^{4}$, George Halkos, Steriani Matsiori ${ }^{5}$, Mirka Laurila-Pant ${ }^{6}$ czy Telmo Pievani ${ }^{7}$. Natomiast ochrona środowiska sprowadza się raczej do usuwania szkodliwych skutków ludzkiej działalności, w tym obszarze badania prowadzili z kolei: Abdul G. Olabi ${ }^{8}$, Julian Rode ${ }^{9}$ czy Folke Ölander, John Thøgersen ${ }^{10}$.

Ochrona przyrody i środowiska jest niezmiernie ważna, na co wskazuje Główny Inspektorat Ochrony Środowiska w swoich cyklicznych raportach. W ostatnim z 2017 r. poinformowano, że większość z 52 gatunków zwierząt wymaga ochrony ${ }^{11}$. Gatunki zwierząt w dobrej kondycji stanowią niespełna $25 \%$ wszystkich badanych, a blisko $60 \%$ gatunków podlega niezadowalającej lub złej ochronie ${ }^{12}$. W raporcie stwierdzono ponadto, że w okresie jesienno-zimowym w Polsce powtarza się zjawisko występowania wysokich stężeń pyłu zawieszonego w powietrzu, zwane potocznie smogiem. W 2016 r. w niektóre zimowe dni poziom dopuszczalny pyłu PM10 przekroczony był

2 Dz. U. 2004, Nr 92, poz. 880.

${ }^{3}$ J. Aronson et al., Nature conservation as if people mattered, „Journal of Nature Conservation" 14(3-4), 2006, s. 260-263.

${ }^{4}$ M. Gross, How can we save forest biodiversity?, „Current Biology” 26(22), 2016, s. R1167R1170.

${ }^{5}$ G. Halkos, S. Matsiori, Environmental attitude, motivations and values for marine biodiversity protection, „Journal of Behavioral and experimental Economics” 69, 2017, s. 61-70.

${ }^{6}$ M. Laurila-Pant et al., How to value biodiversity in environmental management?, „Ecological Indicators” 55, 2015, s. 1-11.

7 T. Pievani, Earth's sixth mass extinction event, „Reference Module in Earth Systems and Environmental Sciences" 2015, <https://doi.org/10.1016/B978-0-12-409548-9.09216-2> [dostęp: 9.08.2017].

8 A.G. Olabi, Developments in sustainable energy and environmental protection, „Energy” 39(1), 2012, s. 2-5.

9 J. Rode, M.L. Menestrel, G. Cornelissen, Ecosystem service arguments enhance public support for environmental protection - but beware of the numbers!, „Ecological Economics” 141 , 2017, s. 213-231.

${ }^{10}$ F. Ölander, J. Thøgersen, Understanding of consumer behaviour as a prerequisite for environmental protection, ,Journal of Consumer Policy” 18(4), 1995, s. 345-385.

11 G. Cierlik et al., Monitoring siedlisk przyrodniczych oraz gatunków roślin $i$ zwierzqt $w$ latach 2013-2014. Biuletyn Monitoringu Przyrody 14: 1-178. Biblioteka Monitoringu Środowiska, Główny Inspektorat Ochrony Środowiska, Warszawa 2015.

12 GIOŚ, <http://www.gios.gov.pl/images/dokumenty/pms/raporty/GIOS_Sygnaly_2016.pdf> [dostęp: 9.08.2017]. 
na przeszło 50\% stanowisk pomiarowych w kraju ${ }^{13}$. Za zanieczyszczenie powietrza w znacznym stopniu odpowiada też pył PM2,5. Pomimo spadku wartości większości wskaźników dla roku 2015, na obszarach dużych miast i aglomeracji środkowej i południowej Polski wskaźniki średniego narażenia pyłu PM2,5 przekroczyły pułap dopuszczalnych jego stężeń. Przyczyną była przede wszystkim nadmierna emisja pyłu ze źródeł antropogenicznych - do której przyczyniało się głównie spalanie paliw stałych w celach grzewczych i bytowych ${ }^{14}$.

W przypadku monitoringu diagnostycznego rzek w latach 2010-2015 można stwierdzić, że jedynie $1 / 4$ badanych wód powierzchniowych osiagnęła stan dobry. Bardzo dobrego lub dobrego potencjału ekologicznego nie osiagnęła natomiast większość (ok. 70\%) badanych wód. W wodach Morza Bałtyckiego zaobserwowano nadmiar mineralnych form fosforu i azotu, które powoduja masowy rozwój tzw. zakwitów ${ }^{15}$.

\section{PODEJŚCIE TEORETYCZNE}

Przeprowadzone badania opierały się na krytycznej analizie dyskursu, która jest zarówno teoria, jak i metodą jakościową wykorzystywaną w badaniach interdyscyplinarnych. Składa się na nią: zbiór zróżnicowanych ujęć złożonej relacji, jaka panuje między językiem (dyskursem) a innymi elementami procesów społecznych ${ }^{16}$. Poprzez dyskurs wytwarzane sa znaczenia za pośrednictwem wykorzystywanych środków semiotycznych, obejmujacych język werbalny i wizualny. Relacje między dyskursem a niedyskursywnymi elementami zjawisk społecznych wskazuja na społecznie konstruowany charakter tych zjawisk ${ }^{17}$. Powstawanie, utrwalanie, powielanie i modyfikacja procesów społecznych wymaga dialektycznej relacji między znaczeniem (interpretacja) a materialnościa. Ważną cechą języka jest zatem jego właściwość dialogiczna oraz intertekstualność tekstów, co oznacza, że każdy tekst jest „ogniwem w łańcuchu” tekstów, czyli czerpie z innych tekstów, odpowiada na nie i przekształca je $\mathrm{e}^{18}$.

KAD korzysta z teorii i badań społecznych, np. wybiera pewne metody z jednej dyscypliny i następnie tłumaczy je tak, aby mogły być wykorzystane $\mathrm{w}$ innej dyscyplinie ${ }^{19}$. Przedmiotem badawczym nie jest język sam w sobie, ale problemy i kwestie życia społecznego, związane np. z degradacją środowiska.

${ }^{13}$ GIOŚ, <http://www.gios.gov.pl/images/dokumenty/pms/raporty/GIOS_Sygnaly_2016.pdf> [dostęp: 9.08.2017].

14 Ibidem.

15 Ibidem.

${ }^{16}$ A. Duszak, N. Fairclough (red.), Krytyczna analiza dyskursu: interdyscyplinarne podejście do komunikacji społecznej, Universitas, Kraków 2008.

17 Ibidem.

${ }_{18}$ M. Bakhtin, The dialogical imagination, M. Holquist (ed.), C. Emerson, M. Holquist (trans.), University of Texas Press, Austin 1981.

19 B. Bernstein, The Structuring of Pedagogic Discourse, Routledge, London 1990. 
Dyskurs może być traktowany jako sposób działania i interakcji. Inną ważną cechą dyskursu jest zdolność wpływania na punkt widzenia i opinie innych. $\mathrm{Z}$ władzą tą wiąże się $\mathrm{z}$ kolei ideologia, która jest formą reprezentacji tych aspektów życia społecznego, które wyrażają interesy zbiorowe. Należy na koniec zaznaczyć, że wybór metody analizy tekstu zależy od konkretnego obiektu badań ${ }^{20}$.

Krótka charakterystyka KAD pozwala przystapić do przybliżenia magazynów, z których artykuły zostały poddane badaniu, a mianowicie $N$ i TP. Pierwszy numer $N$ - tygodnika społeczno-politycznego, ukazał się 2 września 2001 r. jako polskie wydanie amerykańskiej edycji „Newsweeka” ${ }^{21}$. Wydawany jest on przez Ringier Axel Springer Polska ${ }^{22}$. Stałymi rubrykami $N$ sa: Peryskop, Polska, Świat, Biznes, Społeczeństwo, Kultura i nauka. Objętość tygodnika zależy od liczby i długości tekstów, a zatem waha się od 98 do 130 stron, w przypadku wydań specjalnych sa to nawet 202 strony. Tygodnik posiada witrynę internetowa, na której dostępne jest jego wydanie cyfrowe.

Z kolei TP jest katolickim tygodnikiem społeczno-kulturalnym; jego pierwszy numer pojawił się na polskim rynku prasy 24 marca 1945 r.; zawiera on następujące działy: Obraz tygodnia, Kraj, Wiara, Świat, Historia, Nauka, Kultura, Smaki i Felietony. Liczba stron pisma mieści się w przedziale 68-98, a w przypadku wydań specjalnych dochodzi ona do $116^{23}$. Tygodnik posiada stronę internetowa, na której można znaleźć fragmenty wybranych artykułów wydawanych w wersji papierowej. Właścicielami czasopisma są: Fundacja Tygodnika Powszechnego oraz Fundacja Centrum Kopernika ${ }^{24}$.

\section{METODOLOGIA BADAWCZA}

Celem podjętego badania jest porównanie dyskursów prezentowanych przez dwa tygodniki, które pełnią rolę opiniotwórcza, i które skierowane sa do różnych grup odbiorców. $N$ jest magazynem o charakterze liberalno-lewicowym, natomiast TP - liberalno-katolickim. Przekaz obu tygodników jest skierowany do czytelników o odpowiadajacych im poglądach i przekonaniach. Rezygnacja z wyboru pism bardziej „odległych” światopoglądowo, których analiza byłaby wskazana, wynikała z następujących czynników: niewielkiej liczby artykułów o tematyce środowiskowej, lokalnego zasięgu czy utrudnionego dostępu do numerów archiwalnych niektórych czasopism. Wspomniany charak-

${ }^{20}$ A. Duszak, N. Fairclough (red.), op. cit.

21 Średnia sprzedaż tygodnika w 2016 r. wynosiła 113900 egz., dane wg ZKDP <http://www. wirtualnemedia.pl/artykul/gosc-niedzielny-na-czele-sprzedazy-tygodnikow-opinii-w-i-polroczu2016-wprost-z-najwiekszym-spadkiem> [dostęp: 21.07.2017].

22 Zob. <https://pl.wikipedia.org/wiki/Newsweek_Polska> [dostęp: 19.07.2017].

${ }_{23}$ Średnia sprzedaż tygodnika w 2016 r. wyniosła 22200 egz., dane wg ZKDP, <http://www. wirtualnemedia.pl/artykul/rosnie-sprzedaz-tygodnika-powszechnego-najwiecej-stracily-wprost-inewsweek-31-tys-egz-faktow-i-mitow> [dostęp: 7.08.2017].

24 Zob. <https://pl.wikipedia.org/wiki/Tygodnik_Powszechny> [dostęp: 8.08.2017]. 
ter $N$ i TP stanowi główną zmienną uwzględnioną w niniejszym artykule, na podstawie której sformułowane zostały następujące ogólne oraz szczegółowe problemy i hipotezy badawcze:

1) Czy zagadnienie ochrony przyrody i środowiska częściej pojawiało się w dyskursie $N$ niż $T P$ ?

2) Czy w $N$ szerzej propagowano zachowania przyjazne przyrodzie i środowisku niż w $T P$ ?

3) Czy kwestie środowiskowe prezentowane były w dyskursach prasowych częściej z perspektywy globalnej czy krajowej?

4) Czy za potrzebą ochrony przyrody i środowiska bardziej przemawiały argumenty ekonomiczne czy może te natury moralnej?

H1. Temat ochrony przyrody i zagrożeń środowiska w latach 2015-2016 częściej był podejmowany w $N$ niż w $T P$.

H2. W dyskursie $N$ szerzej rozpowszechniano postawy przyjazne przyrodzie i środowisku niż w TP.

H3. Kwestie środowiskowe i przyrodnicze w $N$ prezentowane były częściej z perspektywy globalnej, natomiast w $T P-$ z perspektywy krajowej.

H4. Potrzeba ochrony przyrody i środowiska w TP bardziej uzasadniana była względami ekonomicznymi, natomiast w $N$ - raczej względami moralnymi.

Sposób sformułowania problemów i hipotez badawczych wynika z przekonania, że w czasopiśmie o charakterze lewicującym, które z założenia powinno hołdować zasadzie równości czy wspólnotowości, tematowi ochrony przyrody i środowiska nadaje się większą wagę niż w czasopiśmie katolickim, w którym - jak można przypuszczać - interesy człowieka i lokalność będą w dyskursie stawiane wyżej niż interesy przyrody czy ponadkrajowy zasięg.

W celu weryfikacji zaproponowanych hipotez do analizy wybrane zostały następujące wątki KAD:

- wytwarzanie przez dyskurs wspólnych poglądów, przekonań i wartości w obliczu pogarszającego się stanu środowiska ${ }^{25}$,

- prezentowanie przez dyskurs wymiaru teoretycznego i jego przełożenie na działania praktyczne ${ }^{26}$,

- przedstawianie w dyskursie mikrokontekstów ${ }^{27}$,

- kształtowanie tożsamości zbiorowejej

- pełnienie dystopijnej (pesymistycznej) i utopijnej (optymistycznej) funkcji ${ }^{29}$.

Zanim dokonana zostanie analiza jakościowa dyskursu, w tabelach 1 i 2 przedstawione zostały dane statystyczne na temat badanych tekstów.

${ }^{25}$ S. Bernecker, F.I. Dretske (eds.), Knowledge: Readings in Contemporary Epistemology, OUP, Oxford 2000.

${ }^{26}$ R. de Beaugrande, Theory and practice in the discourse of language planning, „World Englishes" 18(2), 1999, s. 107-121.

${ }_{27}$ T.A. van Dijk, Macrostructures: An Interdisciplinary Study of Global Structures in Discourse, Interaction and Cognition, L. Erlbaum Associates, Hillsdale1980.

${ }^{28}$ B. Giesen, Die Intelektuellen und die Nation, Suhrkamp Giesen, Frankfurt 1993; S.N. Eisenstadt, The construction of collective identities. Some analytical and comparative indications, „European Journal of Social Theory” 1(2), 1998, s. 229-254.

${ }^{29}$ L. Chouliaraki, Spectacular ethics, „Journal of Language and Politics” 3(2), 2005. 


\section{Tabela 1}

Charakterystyka tekstów dotyczących ochrony przyrody i środowiska w $N$ i TP w latach 2015-2016

\begin{tabular}{|c|c|c|c|c|}
\hline Rok & Numer & Dzień/miesiąc & $\begin{array}{l}\text { Liczba } \\
\text { stron }\end{array}$ & $\begin{array}{c}\text { Liczba } \\
\text { zdjęć }\end{array}$ \\
\hline \multicolumn{5}{|c|}{ Newsweek Polska } \\
\hline \multirow[t]{3}{*}{2015} & 3 & 12 stycznia & 3 & 3 \\
\hline & 22 & 25 maja & 3 & 3 \\
\hline & 28 & 6 lipca & 4 & 4 \\
\hline \multirow[t]{3}{*}{2016} & 13 & 21 marca & 4 & 2 \\
\hline & 39 & 19 września & 4 & 8 \\
\hline & 51 & 12 grudnia & 4 & 1 \\
\hline Suma & $\begin{array}{l}6 \text { numerów } \\
\text { (artykułów) }\end{array}$ & $\begin{array}{l}\text { 1× styczeń, marzec, } \\
\text { maj, lipiec, wrzesien, } \\
\text { grudzień }\end{array}$ & 22 & 21 \\
\hline \multicolumn{5}{|c|}{ Tygodnik Powszechny } \\
\hline \multirow[t]{5}{*}{2015} & 19 & 10 maja & 2 & 1 \\
\hline & 29 & 19 lipca & 3 & 1 \\
\hline & 30 & 26 lipca & 2 & 1 \\
\hline & 39 & 27 września & 2 & 2 \\
\hline & 46 & 15 listopada & 1 & 0 \\
\hline \multirow[t]{8}{*}{2016} & 4 & 24 stycznia & 3 & 1 \\
\hline & 8 & 21 lutego & 4 & 2 \\
\hline & 16 & 17 kwietnia & 3 & 1 \\
\hline & 22 & 29 maja & 2 & 1 \\
\hline & 27 & 3 lipca & 3 & 1 \\
\hline & 34 & 21 sierpnia & 3 & 2 \\
\hline & 34 & 21 sierpnia & 1 & 1 \\
\hline & 46 & 13 listopada & 3 & 1 \\
\hline Suma & $\begin{array}{l}12 \text { numerów } \\
\text { (13 artykułów) }\end{array}$ & $\begin{array}{l}\text { 1×styczeń, luty, } \\
\text { kwiecień, wrzesień, } \\
2 \times \text { maj, sierpień, } \\
\text { listopad, } 3 \times \text { lipiec }\end{array}$ & 32 & 15 \\
\hline
\end{tabular}

Źródło: badania własne na podstawie tekstów opublikowanych w Ni TP. 


\section{Tabela 2}

Szczegółowe wątki poruszane w N i TP w latach 2015-2016

\begin{tabular}{|c|c|c|}
\hline \multirow{2}{*}{ Główne wątki artykułów } & \multicolumn{2}{|c|}{ Rok } \\
\hline & 2015 & 2016 \\
\hline \multicolumn{3}{|l|}{ Newsweek Polska } \\
\hline \multicolumn{3}{|l|}{ Pozytywne aspekty } \\
\hline Budowa ekologicznych domów & 1 & - \\
\hline Bakterie rozkładające plastik & - & 1 \\
\hline $\begin{array}{l}\text { Wzrost populacji roślin i zwierząt w strefie } \\
\text { czarnobylskiej }\end{array}$ & - & 1 \\
\hline Ochrona Puszczy Białowieskiej & - & 1 \\
\hline \multicolumn{3}{|l|}{ Negatywne aspekty } \\
\hline Masowe wymieranie gatunków & 1 & - \\
\hline Wymieranie morświnów w Bałtyku & 1 & - \\
\hline Suma & 3 & 3 \\
\hline \multicolumn{3}{|c|}{ Tygodnik Powszechny } \\
\hline \multicolumn{3}{|l|}{ Pozytywne aspekty } \\
\hline Budowa ekologicznych kościołów & 1 & 1 \\
\hline Ochrona Puszczy Białowieskiej & - & 2 \\
\hline Poprawa warunków życia zwierząt hodowlanych & - & 1 \\
\hline $\begin{array}{l}\text { Propagowanie przez papieża Franciszka postaw } \\
\text { proekologicznych }\end{array}$ & - & 1 \\
\hline \multicolumn{3}{|l|}{ Negatywne aspekty } \\
\hline $\begin{array}{l}\text { Zagrożenia zdrowia spowodowane rozwojem energetyki } \\
\text { wiatrowej }\end{array}$ & 1 & - \\
\hline Choroby spowodowane zanieczyszczeniem powietrza & 1 & - \\
\hline Wymieranie gatunków & 1 & - \\
\hline Wycinanie lasów w Azji & 1 & - \\
\hline Traktowanie dzikich zwierząt jako atrakcji turystycznej & - & 2 \\
\hline $\begin{array}{l}\text { Katastrofa ekologiczna - lawina odpadów górniczych } \\
\text { w brazylijskiej wiosce }\end{array}$ & - & 1 \\
\hline Suma & 5 & 8 \\
\hline
\end{tabular}

Źródło: badania własne na podstawie tekstów opublikowanych w N i TP. 
Warto też sprecyzować dane zawarte w tabelach 1 i 2 - wszystkie artykuły traktujące o ochronie przyrody i środowiska, które ukazały się w $N$, zamieszczone zostały w dziale Nauka, dodatkowo prawie wszystkie, poza jednym, zostały napisane przez jednego dziennikarza. W przypadku TP artykuły pojawiały się w różnych działach, takich jak: Nauka, Świat, Kraj i Wiara; były ponadto pisane przez różnych autorów (tylko w dwóch przypadkach teksty miały tego samego autora).

\section{ANALIZA DYSKURSU}

W $N$ w badanym okresie pojawiło się więcej artykułów dotyczących ochrony przyrody niż środowiska. Przybliżanie tych kwestii w niewielkim jednak stopniu przekładało się na propagowanie wśród czytelników postaw przyjaznych środowisku ${ }^{30}$. Jedyne działania, jakie były w tekstach przedstawiane, podejmowali naukowcy, których motywacja nie zawsze bywa czysto altruistyczna, czego przykładem jest fragment: „[...] prof. Karpiński chciałby [...] wykorzystać procesy zachodzące w roślinach do produkcji prądu [...]. Każdy liść na ziemi jest potencjalnym generatorem mikrostrumieni pary wodnej. Prof. Karpiński ma pomysł, jak wykorzystać tę właściwość, aby rośliny stały się żywymi, ekologicznymi elektrowniami. Posłużyć do tego mają tak zwane nanoturbiny [...]" (22/2015). Z kolei niektóre badania prowadzone na świecie mają tak istotne znaczenie dla środowiska, że poświęca się im miejsce w $N$, o czym może świadczyć następujący cytat: „W poszukiwaniu nowych możliwości [neutralizowania zanieczyszczeń] japońscy naukowcy pobrali z wysypisk śmieci 250 próbek plastiku i przeskanowali je w poszukiwaniu mikroorganizmów, które powodują znaczące uszkodzenia w tworzywie. I wtedy znaleźli bakterię Ideonella sakaiensi 201-F6" (13/2016). Fragment ten pośrednio wskazuje też na podmiot moralnie odpowiedzialny za degradowanie środowiska jest nim człowiek nadmiernie produkujący tworzywa sztuczne i zaśmiecający nimi ziemię. W dyskursie brakuje jednak wyraźnych wskazań, jak zwykli czytelnicy - do których w znacznej mierze tygodnik jest skierowany - powinni się zachowywać w kontaktach z przyrodą i jak mogliby chronić środowisko.

W przeciwieństwie do dyskursu $N$, w TP kładzie się silny akcent na podejmowanie działań, które wiążą się z kwestią ochrony przyrody, choć nie zawsze jej sprzyjaja, przykładem jest następująca relacja: „Dowiedziałam się, że ma powstać wiatrak [...] niedaleko mojego domu. Postanowiłam walczyć - mówi Pani Katarzyna [...] naczytałam się o chorobach [...]. Zrobiłam listę protestacyjna. Chodziłam po ludziach, tłumaczyłam czym to grozi, i pytałam: podpiszecie? [...] podpisywały całe rodziny. Inwestor ustapił. Nowe wiatraki nie powstały. Ja doprowadzam sprawy do końca" (29/2015). W tym przypadku wykazano, jak motywy ekonomiczne oraz moralne, które moga skłaniać do ochrony przyrody, ustapiły obawom i potencjalnym zagrożeniom. Czytelnik odbierajacy taki przekaz uświadamia sobie, że także zwykły obywatel może

${ }^{30}$ R. de Beaugrande, op. cit. 
skutecznie wpływać na lokalną politykę ekologiczną. Inny fragment dotyczy uprawiania świadomej turystyki - której elementem coraz częściej jest kontakt z dzikimi zwierzętami - i zachęcania ludzi przez dyskurs do wykazywani inicjatywy, np: „Zadawajmy w placówkach pytania. Dobrze działające, etyczne organizacje z chęcią opowiedzą nam o swojej działalności [...]. Jeśli jednak pracownicy zaczną kręcić i wymigiwać się od odpowiedzi, uważajmy - najprawdopodobniej mają coś do ukrycia. Pamiętajmy większość niezrzeszonych atrakcji turystycznych jest nieregulowana - co oznacza, że nikt nie dba o zwierzęta [...]” (34/2016). W ten sposób czytelnik dowiaduje się, że człowiek dla zysku jest skłonny znęcać się nad egzotycznymi zwierzętami - proceder taki jest w dyskursie piętnowany. Ponadto za pośrednictwem tekstu apeluje się do sumień, które powinny zabraniać ludziom korzystania z tego typu wątpliwych atrakcji turystycznych. Przez dyskurs pobudza się świadomość środowiskowa, której elementem jest cenienie wyżej wartości moralnych niż korzyści materialnych.

$\mathrm{Na}$ uwagę zasługują również przytoczone fragmenty encykliki papieża Franciszka: „zmiana stylu życia może spowodować wywieranie zdrowej presji na tych, którzy sprawują władzę polityczna, gospodarczą i społeczną. Dzieje się tak gdy ruchom konsumenckim udaje się [...] wpłynąc na zmianę funkcjonowania przedsiębiorstw, zmuszając je do rozważenia oddziaływania na środowisko [...]. Małe gesty moga przynosić duże oszczędności. I przysłużyć się planecie” (4/2016). Należy zauważyć, że przez dyskurs TP kształtowana była aktywna postawa wśród czytelników względem środowiska i przyrody, odmiennie niż w przypadku $N$, w którym ograniczano się głównie do prezentowania działań podejmowanych przez elitę społeczeństwa - naukowców. Tym samym podejście teoretyczne przedstawiane w TP w wyższym stopniu przekłada się na działania praktyczne, które może podjąć praktycznie każdy człowiek ${ }^{31}$.

Przez dyskurs wyrażana jest także akceptacja względem określonych poglądów i wartości ${ }^{32}$, w przypadku $N$ - wartości, które stanowi kruche bogactwo świata przyrodniczego, na co wskazuje fragment: „Być może w końcu doprowadzimy do tego, że na [...] Ziemi zostaną tylko wszędobylskie owady i drobne gryzonie, zwłaszcza superodporne szczury. A w doszczętnie zdewastowanym świecie nie przetrwają również ludzie” (28/2015). Krzewieniu wartości przyrodniczych towarzyszy często propagowanie wartości ekonomicznych, o czym świadczy z kolei cytat dotyczący Puszczy Białowieskiej: „Ściać drzewo i je sprzedać, to da się zrobić raz, a potem trzeba czekać kolejne 20 czy 30 lat, żeby nowe urosło. Jeśli pozwolisz lasowi rosnać i się starzeć, ludzie będą przyjeżdżać i płacić tylko po to, żeby nacieszyć się jego widokiem" (39/2016). Przyroda jest w dyskursie $N$ prezentowana nieco instrumentalnie. Wskazuje się na potrzebę jej ochrony głównie ze względu na korzyści, jakie daje człowiekowi, a nie na jej samoistny walor. Podobnie w innym fragmencie wskazuje się na równie ważną wagę wartości ekonomicznych: „[...] przeznaczenie energii z każdego zaabsorbowanego przez chlorofil w liściu fotonu jest zróżnicowane i regulowane [...], 75\% [roślina] przetwarza bezpośrednio na ciepło, które jest wypromieniowywane i rozpraszane w otoczeniu. Czyli po prostu się marnuje [...]” (22/2015). Kreowanie takich

31 R. de Beaugrande, op. cit.

32 S. Bernecker, F.I. Dretske, op. cit. 
wartości wiąże się ponadto z konstruowaniem przez podmioty posiadajace władzę nad procesem dyskursywnym - zbiorowej tożsamości ${ }^{33}$. U podstaw tworzenia tej wspólnej tożsamości może leżeć m.in. fakt, że tygodnik występuje pod amerykańską marką Newsweek, co wymaga utrzymywania preferowanej przez nią linii.

W dyskursie TP kształtowane i propagowane sa podobne wartości jak w $N$, czyli wartości przyrodnicze oraz ekonomiczne, o znacznej roli tych pierwszych świadczy fragment dotyczący Puszczy Białowieskiej: „[...] istnienie naturalnego ekosystemu leśnego stanowi bezcenną wartość, godną ochrony. [...] W hierarchii wartości alternatywnej w stosunku do tej, gdzie ochrona krajobrazu, ekosystemów, bioróżnorodności i poszczególnych gatunków zajmuje poczesne miejsce, liczą się inne wartości: korzyści materialne, interesy grupowe, zaspokajanie indywidualnych ambicji. [...] To, co zagraża przyrodzie Puszczy Białowieskiej [...], to nie kornik drukarz [...]. Chodzi o głęboki kryzys wartości [...]" (27/2016). Szerzej rzecz ujmując, w dyskursie wskazuje się na kryzys w sferze moralności. O tym, że dla niektórych ważne są wartości ekonomiczne, informuje téz następujący fragment: „Jestem zwolennikiem inwestowania w [...] [panele fotowoltaiczne] w kościołach. Energia nie jest tania, kościoły coraz trudniej utrzymać. Dobrze byłoby, gdyby powstał specjalny program na rzecz fotowoltaiki w Polsce [...] - mówi ks. Lenda" (46/2016). Prezentowaniu wspomnianych wartości podobnie towarzyszy kształtowanie zbiorowej tożsamości ${ }^{34}$, której podstawę w tym przypadku stanowi liberalno-katolicki charakter magazynu, podkreślający, iż przyroda jest dziełem Boga i człowiek powinien się o nią troszczyć, a nie nadmiernie ją eksploatować.

W dyskursie $N$ prezentowane sa ponadto nieliczne zdarzenia i sytuacje doświadczane przez konkretne osoby w wyniku bezpośrednich interakcji, czyli tzw. mikrokonteksty ${ }^{35}$ : „Jeździliśmy drogami [...] i wypatrywaliśmy żubrów, [...] Czasami przez kilka dni nie spotykaliśmy ani jednego. Ale kiedy zobaczyliśmy je na śnieżnym tle, jawiły się niczym zwierzęta z mitów. Potem usłyszeliśmy ich wspaniały, niewiarygodny tętent" (39/2016). Cytat ten uwidacznia podziw dla wspomnianych zwierząt, czemu towarzyszy propagowanie wartości estetycznych. Przykład ten stanowi jednak wyjątek, na ogół w dyskursie pojawiał się opis prowadzonych przez naukowców badań, a nie ich subiektywnych odczuć czy osobistych przeżyć. Fragment ten wskazuje ponadto, że rzadkie, cenne i piękne gatunki zwierząt, zasługujące na szczególną ochronę, moga występować lokalnie - w wybranych obszarach rodzimego kraju, a nie tylko w najodleglejszych zakatkach świata.

Częściej niż w $N$ mikrokoteksty prezentowane były w $T P$, ilustrację stanowi wspomniana relacja pani Katarzyny czy historia Helen Browling - pionierki ekologicznych gospodarstw w Anglii. „[...] zmieniła [ona] fermę, która przejęła po ojcu [...] mieszka tu 3 tys. świń, które przez większość życia swobodnie się poruszają [...]. Są wolne i tak szczęśliwe, jak to możliwe. Często spotykam się z komentarzem po co to wszystko, skoro i tak je zabijemy i zje-

\footnotetext{
33 S.N. Eisenstadt, op. cit.; B. Giesen, op. cit.

34 Ibidem.

35 T.A. van Dijk, op. cit.
} 
my? [...] Wydaje się że wiązała nas pradawna umowa: my, ludzie zapewniamy im [...] lepsze życie, niż miałyby żyjąc dziko, a one pozwalają nam korzystać z ich mleka, jaj i mięsa" (22/2016). Na podstawie prezentowanego fragmentu można stwierdzić, że ochrona przyrody, w tym zwierząt, stanowi ważną kwestię o zasięgu globalnym. Rola mikrokontekstów w dyskursie TP jest znaczna dzięki przedstawianiu relacji konkretnych osób, tym samym kwestia środowiska i przyrody zostaje urealniona, przez co bardziej wpływa na wyobraźnię czytelnika i kształtuje jego świadomośćc ${ }^{36}$.

Z sześciu artykułów $N$, które dotyczyły kwestii ochrony przyrody i środowiska, w czterech przypadkach prezentowano optymistyczny obraz rzeczywistości, napawający nadzieją na skuteczną poprawę stanu środowiska, najlepszym tego przykładem jest fragment: „Fakt, że od 30 lat nie ma [w strefie czarnobylskiej - K.C.] ludzi okazał się czynnikiem niezwykle sprzyjającym przyrodzie, która rozpanoszyła się tak, że przykryła zielenią ruiny domów. Zwierzęta czują się tam świetnie, nie niepokojone przez nasz gatunek" (51/2016). W pewnej mierze optymistyczną funkcję pełni też dyskurs wizualny ${ }^{37}$. Prezentowane w artykułach fotografie przedstawiaja: piękne gatunki zwierząt, ekologiczne budowle oraz sposoby ochrony środowiska, czego przykładem jest zdjęcie sarkofagu znajdującego się nad elektrownią w Czarnobylu. Pesymistyczna funkcja, jaka przejawia się w dyskursie, dotyczy natomiast przedstawiania zjawiska wymierania gatunków - zarówno w tekście, jak i obrazie - przez fotografie gatunków zagrożonych wyginięciem.

$\mathrm{Z}$ kolei $T P \mathrm{w}$ większej mierze pełnił funkcję dystopijną niż utopijna. Pesymistyczny przekaz zawarty jest $\mathrm{w}$ artykułach dotyczących wymierania gatunków czy chorób spowodowanych zanieczyszczeniem środowiska, natomiast optymistyczny - w tekstach na temat wdrażania ekologicznych technologii czy poprawy warunków życia zwierząt, np.: „kury są w awangardzie zwierzęcej rewolucji na Wyspach i poprawa warunków ich życia to najbardziej spektakularny dowód zwycięstwa etyki w sprawach ekonomicznych" (22/2016). W przypadku dyskursu wizualnego prezentowane w TP zdjęcia przedstawiaja szerokie spektrum, od wiejskiego lub miejskiego krajobrazu, przez zagrożone i wykorzystywane zwierzęta, aż po wizerunki samych ekologów. Skłaniają one czytelników do optymizmu, pesymizmu, a niekiedy także wywołują obojętność.

\section{ZAKOŃCZENIE}

W wyniku przeprowadzonej analizy obu dyskursów można przystapić do ich porównania - wskazania podobieństw i różnic oraz do weryfikacji zaproponowanych w artykule hipotez. Sprawdzając poprawność pierwszego założenia, należy przytoczyć wnioski z analizy ilościowej. $\mathrm{Z}$ danych zawartych $\mathrm{w}$ tabeli 1 i 2 wynika, że w latach 2015-2016 dwa razy więcej artykułów na temat ochrony przyrody i środowiska ukazało się w TP niż w $N$. W przypadku $N$

\footnotetext{
${ }^{36}$ Ibidem.

${ }^{37}$ L. Chouliaraki, op. cit.
} 
ich liczba była stała, natomiast jeśli chodzi o TP, więcej tekstów pojawiło się w 2016 niż w 2015 r. Tylko dwa tematy z szesnastu były w obu tygodnikach tożsame, dotyczyły one: ochrony Puszczy Białowieskiej i wymierania gatunków. Przeciętna długość artykułów była jednak większa w przypadku $N$, co może wynikać, z faktu, że więcej zamieszczano w nim fotografii niż w TP. Jedynym odnotowanym podobieństwem jest to, że w obu tygodnikach częściej podejmowane było zagadnienie ochrony przyrody niż ochrony środowiska. Na podstawie tych cząstkowych wniosków należy zatem odrzucić pierwszą z zaproponowanych hipotez. Większą wagę do kwestii ochrony przyrody przywiązywano w TP, o czym świadczy znaczna liczba opublikowanych na ten temat artykułów.

Weryfikacja drugiej hipotezy wymaga zestawienia czastkowych wniosków z przeprowadzonej analizy jakościowej. Niewątpliwie w obu dyskursach przedstawiono ważne problemy, jakie występują w przyrodzie i środowisku. Podstawową różnicą między dwoma dyskursami jest przełożenie wymiaru teoretycznego na praktyczny, które w pewnym stopniu nastapiło w obu dyskursach, ale dotyczyło innych podmiotów. W dyskursie $N$ na ogół przedstawiano inicjatywy podejmowane przez naukowców, rzadziej natomiast prezentowane były interakcje zachodzące „twarzą w twarz” między zwykłymi ludźmi - nienależącymi do elity społeczeństwa posiadającej odpowiednią wiedzę, umiejętności i środki finansowe na badania. Mikrokonteksty częściej pojawiały się w TP, przez co poniekąd stawały się „bliższe” czytelnikom, którzy mogli porównywać się do przedstawianych osób, a nawet brać z nich przykład. Do podobnego wzorowania się raczej nie dochodziło w przypadku działań naukowców prezentowanych w $N$, gdyż podejmowanie takich inicjatyw pozostawało na ogół poza możliwościami czytelników. Dlatego dyskurs $N$ pełnił bardziej funkcję informacyjną i poznawczą niż praktyczna. Natomiast dyskurs $T P$ w sposób pełniejszy rozwijał świadomość przyrodniczą i środowiskowa, gdyż poza przekazywaniem wiedzy i krzewieniem odpowiednich wartości oddziaływał on na szerokie grono odbiorców przez propagowanie wśród nich prostych działań na rzecz przyrody. Podkreślić zatem należy, że inicjatywy propagowane w TP były podejmowane przez zwykłych ludzi, takich, jacy są na ogół jego czytelnikami. Natomiast przedsięwzięcia badaczy przytaczane w $N$ raczej nie zachęcały czytelników do podejmowania inicjatyw na rzecz przyrody i środowiska. Tym samym należy odrzucić również druga z zaproponowanych hipotez. Na uwagę zasługuje też fakt, że dyskurs $N$ w wyższym stopniu pełnił funkcje utopijne - w sposób optymistyczny prezentując możliwości poprawy kondycji przyrody. W przypadku dyskursu wizualnego funkcja ta była trochę bardziej neutralna, gdyż przez obraz prezentowane były m.in. zagrożone gatunki zwierząt oraz budowle, których rolą jest ochrona środowiska. Z kolei dyskurs TP nieco częściej pełnił funkcje dystopijne, co przejawiało się w przedstawianiu negatywnego wpływu stanu środowiska na jakość ludzkiego życia. W przypadku prezentowanych w nim fotografii przedstawiających różne obiekty podobnie można stwierdzić, że dyskurs wizualny $T P$ pełnił po części funkcję dystopijna, utopijna, ale i neutralną.

Z kolei w celu weryfikacji trzeciej szczegółowej hipotezy należy odwołać się do analizy ilościowej. Na podstawie danych z tabeli 2 można stwierdzić, że li- 
czebnie więcej tematów ze świata ukazało się w TP - osiem z trzynastu (61\%); natomiast proporcjonalnie, nieznacznie więcej artykułów o ponadkrajowym zasięgu publikował $N$ (cztery z sześciu, czyli 66\%). Uwzględniając wyniki procentowe, z pewną ostrożnością można by przyjąć trzecią z zaproponowanych hipotez, niemniej pożądane byłyby dalsze badania w tym zakresie.

Jeszcze trudniej jest dokonać weryfikacji czwartej hipotezy, gdyż względy ekonomiczne i moralne w zbliżonym stopniu przeplatały się w artykułach obu tygodników. Przyczyna krzewienia obu rodzajów wartości tkwiła jednak w odmiennych źródłach, w przypadku $N$ - lewicowych, propagujących zasadę równości i rozwój nauki oraz technologii, z kolei w przypadku TP - katolickich, kładących nacisk na szacunek do przyrody jako do dzieła Stwórcy, z którego bogactw człowiek, dla własnego dobra i interesu, powinien korzystać z umiarem. Tym, co dodatkowo zasługuje na uwagę, to fakt, że w przypadku TP położono nieco większy nacisk na krytykę motywów ekonomicznych i propagowanie motywów moralnych jako tych, którymi należy się kierować w podejmowaniu działań na rzecz ochrony przyrody i środowiska. Sformułowane wnioski w przypadku TP wskazujące nieznaczną przewagę argumentów moralnych uzasadniających ochronę przyrody są niewystarczajace, by odrzucić czwarta hipotezę. W celu potwierdzenia tej sugestii konieczne będzie przeprowadzenie dalszych badań.

Zważywszy, że badane tygodniki trafiają do szerokiego grona odbiorców, powinny one kłaść większy nacisk na kształtowanie świadomości ekologicznej, gdyż przyroda i środowisko w znacznej mierze wpływają na jakość ludzkiego życia, a za ich stan w dużym stopniu odpowiada właśnie człowiek. Co więcej, dla wspólnego dobra periodyki powinny bardziej propagować wśród czytelników podejmowanie działań proekologicznych. Dyskurs prasowy stanowi istotne narzędzie, które jeśli tylko będzie lepiej wykorzystane, może pomóc w ochronie przyrody, której człowiek też jest częścią.

dr Karolina Cynk

Uniwersytet Rzeszowski

rss@ur.edu.pl

\author{
ENVIRONMENTAL PROTECTION AND NATURE CONSERVATION \\ IN THE DISCOURSE OF NEWSWEEK AND TYGODNIK POWSZECHNY
}

$$
\text { Sum mary }
$$

The purpose of this article is to conduct a critical discourse analysis (CDA). Two weeklies Newsweek Polska and Tygodnik Powszechny have been selected for the analysis. The focus was placed on texts on nature conservation and environmental protection, published in 2015 and 2016. The CDA is both a theory as well as a method of study. In the first part of article the concepts: nature conversation and environmental protection are defined and characterised using the CDA. In the second part a quantitative and qualitative analysis of discourse is performed. The results of the analysis indicate that Newsweek has published more articles on nature conservation and they promoted more broadly nature friendly attitudes in comparison with the texts published in Tygodnik Powszechny. In addition, in Newsweek there were proportionally more topics which analysed the issue from a global perspective. When it comes to motives, economic and moral arguments were presented in similar proportions in both weeklies. 
